Check for updates

Cite this: RSC Adv., 2017, 7, 18821

Received 8th February 2017

Accepted 22nd March 2017

DOI: 10.1039/c7ra01608e

rsc.li/rsc-advances

\section{An investigation of mass transfer-reaction kinetics of NO absorption by wet scrubbing using an electrolyzed seawater solution}

\author{
Zhitao Han, (D) Shaolong Yang, (D)* Dongsheng Zhao, Bojun Liu, Xinxiang Pan \\ and Zhijun Yan
}

\begin{abstract}
The mass transfer-reaction kinetics of $\mathrm{NO}$ absorption by wet scrubbing using electrolyzed seawater was studied in a bench-scale bubbling reactor. The effects of active chlorine concentration, solution $\mathrm{pH}$, absorbent temperature, $\mathrm{NO}$ and $\mathrm{SO}_{2}$ inlet concentrations on $\mathrm{NO}$ absorption rate were investigated. The results showed that the $\mathrm{NO}$ absorption rate significantly increased from $0.41 \times 10^{-5}$ to $1.91 \times 10^{-5} \mathrm{~mol}$ $\mathrm{m}^{-2} \mathrm{~s}^{-1}$ with the active chlorine concentration increasing from 500 to $3100 \mathrm{mg} \mathrm{L}^{-1}\left[\mathrm{Cl}_{2}\right]$. The $\mathrm{NO}$ absorption rate greatly increased from $0.25 \times 10^{-5}$ to $1.58 \times 10^{-5} \mathrm{~mol} \mathrm{~m} \mathrm{~m}^{-2} \mathrm{~s}^{-1}$ with $\mathrm{NO}$ concentration increasing from 250 to $1250 \mathrm{ppm}$. When $\mathrm{SO}_{2}$ inlet concentration increased from 250 to $1250 \mathrm{ppm}$, the $\mathrm{NO}$ absorption rate slightly increased from $1.09 \times 10^{-5}$ to $1.17 \times 10^{-5} \mathrm{~mol} \mathrm{~m}^{-2} \mathrm{~s}^{-1}$. When the solution $\mathrm{pH}$ was in the range of $4-6$, the $\mathrm{NO}$ absorption rate was about $1.5 \times 10^{-5} \mathrm{~mol} \mathrm{~m}^{-2} \mathrm{~s}^{-1}$. The change of the $\mathrm{NO}$ absorption rate was insignificant with the absorbent temperature increasing from 20 to $50{ }^{\circ} \mathrm{C}$. The influential mechanism of the $\mathrm{NO}$ absorption rate was also discussed preliminarily. Furthermore, the $\mathrm{NO}$ absorption process by electrolyzed seawater was pseudo-first-order reaction with respect to NO concentration. A simplified equation of $\mathrm{NO}$ absorption rate was also obtained. The comparison results indicated that the calculated values agreed well with the experimental values.
\end{abstract}

\section{Introduction}

The emission of $\mathrm{NO}_{x}$ from stationary and mobile sources is a major environmental concern due to their detrimental effects (e.g., acid rain, photochemical smog, tropospheric ozone layer depletion and even global warming) on human health and ecosystems. ${ }^{1}$ With the implementation of stringent regulations on $\mathrm{NO}_{x}$ emission, there are eager demands for developing new technologies and improving the currently used methods for $\mathrm{NO}_{x}$ removal from exhaust gas.

Apart from the combustion control methods aimed at reducing the formation of $\mathrm{NO}_{x}$ during the combustion process, there are a lot of post-combustion treatment technologies that can be further divided into two categories: oxidation and reduction methods. The reduction methods mainly include selective catalytic reduction (SCR) and selective non-catalytic reduction (SNCR). ${ }^{2,3}$ SCR can reduce $\mathrm{NO}_{x}$ into $\mathrm{N}_{2}$ in the presence of catalysts and reductants, and its $\mathrm{NO}_{x}$ removal efficiency is very high. However, it usually requires a high catalyst activation temperature, and a large installation space. SCR system is very complex, and its capital and operating cost are very high. For SNCR, a very high reaction temperature of $850-1100{ }^{\circ} \mathrm{C}$ is required to facilitate the reduction reaction between $\mathrm{NO}_{x}$ and

Marine Engineering College, Dalian Maritime University, Dalian 116026, P. R. China. E-mail: dmuyangsl@126.com; Tel: +86-138-9869-2035 reductants. Moreover, an elaborate temperature control is critical for avoiding ammonia slip.

The oxidation methods for $\mathrm{NO}_{x}$ abatement aim at oxidizing NO into higher order nitrogen oxides that can be easily removed by chemical absorption. Recently, numerous chemical oxidants, such as non-thermal plasma, ${ }^{4,5} \quad \mathrm{O}_{3},{ }^{6} \mathrm{KMnO}_{4},{ }^{7} \mathrm{H}_{2} \mathrm{O}_{2},{ }^{8-11}$ $\mathrm{Na}_{2} \mathrm{~S}_{2} \mathrm{O}_{8},{ }^{12,13}$ oxone, ${ }^{14,15} \mathrm{NaClO}_{2},{ }^{16-18} \mathrm{ClO}_{2},{ }^{19} \mathrm{Ca}(\mathrm{ClO})_{2}{ }^{20}$ and $\mathrm{NaClO},{ }^{21,22}$ have been investigated in order to improve the NO removal efficiency of the oxidation methods. Among these oxidants, $\mathrm{NaClO}$ are very attractive for practical applications because it has some obvious advantages such as low cost, strong oxidability, and easy storage and transportation. During the past few decades, the denitration performance and the reaction mechanism of NO removal by $\mathrm{NaClO}$ oxidation have been explored in detail. ${ }^{23-26}$ Guo R. T. et al. studied the absorption kinetics of NO into weakly acidic NaClO solution in a stirred tank reactor. ${ }^{27}$ Deshwal B. R. et al. studied the reaction kinetics of oxidative absorption of NO into NaClO solution in a bubbling reactor. ${ }^{28}$ Recently, Sukheon A. N. et al. proposed the application of electrolyzed seawater to remove NO from marine exhaust gas, which was of great potential in industrial applications such as onshore power plants and ocean-going vessels. ${ }^{29}$

It is well known that, the oxidative components in electrolyzed seawater are active chlorine species, which are the same with commercial $\mathrm{NaClO}$ solution. Yang S. L. et al. conducted the experiments of seawater electrolysis in an undivided cell, and 
studied the $\mathrm{NO}_{x}$ removal by wet scrubbing electro-generated chlorine in a spray reactor. ${ }^{30}$ However, the mass transferreaction kinetics of NO removal by electrolyzed seawater has not been reported yet. The purpose of this study is to investigate the mass transfer-reaction kinetics of NO removal by wet scrubbing using electrolyzed seawater process. The effects of several operating parameters (e.g., such as active chlorine concentration, solution $\mathrm{pH}$, absorbent temperature, NO and $\mathrm{SO}_{2}$ inlet concentrations) on $\mathrm{NO}$ absorption rate are evaluated. A simple NO absorption rate equation is also established. The results will provide a theoretical basis for the numerical simulation of NO absorption by electrolyzed seawater process, and the industrial application of this technology.

\section{Materials and methods}

\subsection{Experimental apparatus}

Fig. 1 shows the schematic diagram of the experimental system, including simulated flue gas unit, bubble column reactor and flue gas analysis system. The bubble column reactor consists of constant temperature water bath, bubble column, thermometer and gas distributor. The height and inner diameter of the bubble column are 600 and $50 \mathrm{~mm}$, respectively. The gas distributor (ISO $4793 \mathrm{P} 4$, pore size 10-15 $\mu \mathrm{m}$ ) used to uniformly distribute the simulated flue gas, is located at the bottom of the bubble column. The constant temperature water bath (Julabo F34-ED Refrigerated/Heating Circulator, Germany) is used to adjust the absorbent temperature to the desired values. A gas analyzer (MRU MGA5, Germany) is used to measure the concentrations of multi pollutants such as $\mathrm{NO}, \mathrm{NO}_{2}$, and $\mathrm{SO}_{2}$. In order to effectively remove moisture from the flue gas before it enters the gas analyzer, an additional electric condenser is used as a drier.

\subsection{Experimental procedures}

The simulated flue gas was prepared continuously by mixing three kinds of gases, $\mathrm{N}_{2}$ pure gas (99.999\%), NO span gas (10.04\% NO with $\mathrm{N}_{2}$ as balance gas), and $\mathrm{SO}_{2}$ span gas $(10.1 \%$ $\mathrm{SO}_{2}$ with $\mathrm{N}_{2}$ as balance gas). The flow rate of each gas from the separate air bottles was metered through mass flow controllers (MFCs, Beijing Sevenstar Electronics Co., Ltd). The inlet

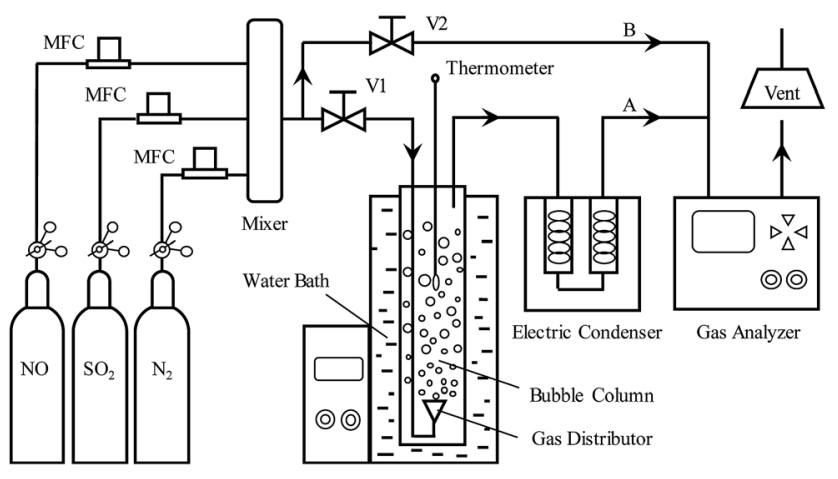

Fig. 1 Schematic diagram of the experimental system. concentrations of gas pollutants were measured using the gas analyzer through gas bypass $\mathrm{B}$.

The electro-generated chlorine was produced by artificial seawater electrolysis in an undivided cell as described previously. $^{30}$ The artificial seawater ( $\mathrm{pH} 8.2$, salinity $23.3 \mathrm{ppt}$ ) was prepared according to the ASTM D1141 standard. ${ }^{1}$ To reduce the deterioration of electro-generated chlorine during the experiments, the electrolyte was stored in a water bath $\left(20{ }^{\circ} \mathrm{C}\right)$ and was shielded from light. For each gas absorption experiment, the absorbent solution was prepared by diluting the electrolyzed seawater with fresh artificial seawater. The initial $\mathrm{pH}$ values of bubbling solution were adjusted to the desired values by adding $\mathrm{HCl}$ solution $\left(1 \mathrm{~mol} \mathrm{~L}^{-1}\right)$ or $\mathrm{NaOH}$ solution $\left(1 \mathrm{~mol} \mathrm{~L}^{-1}\right)$, and were measured by a $\mathrm{pH}$ meter (Mettler-Toledo S210, Switzerland). The active chlorine concentrations (ACCs) in absorbent solution were determined by $N, N$-diethyl- $p$-phenylenediamine (DPD) colorimetric method (ASTM $4500 \mathrm{G}$ ), using a spectrophotometer (Shimadzu UV1800, Japan) at $515 \mathrm{~nm}$. The temperature of bubbling liquid was adjusted to the set value by the water bath. After the inlet concentrations of gas pollutants and solution temperature reached the required values and kept stable, the simulated flue gas was introduced into the bubble column reactor by switching the gas valves of V1 and V2. The gas-liquid reaction occurred under atmospheric pressure. The outlet concentrations of gas pollutants were monitored using the gas analyzer at $10 \mathrm{~s}$ interval. Each experiment was replicated for 3 times and the duration of each test was kept for $15 \mathrm{~min}$. For each experiment, the average concentrations of targeted pollutants measured for the last $10 \mathrm{~min}$ were used as outlet concentrations of pollutants.

To verify NO absorption by wet scrubbing using electrolyzed seawater, the anions of $\mathrm{NO}_{3}{ }^{-}$and $\mathrm{NO}_{2}{ }^{-}$in the scrubbing solution were measured via ion chromatography (Dionex ICS-1500).

\subsection{NO absorption rate}

According to the material balance and the ideal gas equation, the NO absorption rate $\left(R_{\mathrm{NO}}, \mathrm{mol} \mathrm{m} \mathrm{m}^{-2} \mathrm{~s}^{-1}\right)$ can be calculated using the following equation:

$$
R_{\mathrm{NO}}=\frac{Q_{\mathrm{G}} \times\left(C_{\mathrm{NO}, \text { in }}-C_{\mathrm{NO}, \text { out }}\right)}{V_{\mathrm{L}} \times a_{\mathrm{NO}} \times M_{\mathrm{NO}}} \times \frac{1}{60000}
$$

where $Q_{\mathrm{G}}$ is the volumetric flue gas flow rate, $\mathrm{L} \min ^{-1} ; C_{\mathrm{NO}, \text { in }}$ and $C_{\mathrm{NO} \text {,out }}$ are the inlet and outlet concentrations of $\mathrm{NO}$, respectively, $\mathrm{mg} \mathrm{m}^{-3} ; V_{\mathrm{L}}$ is the volume of solution, $\mathrm{L} ; a_{\mathrm{NO}}$ is the interfacial area between gas and liquid per unit volume of the system, $\mathrm{m}^{2} \mathrm{~m}^{-3} ; M_{\mathrm{NO}}$ is the molecular weight of $\mathrm{NO}, 30 \mathrm{~g} \mathrm{~mol}^{-1}$.

\subsection{Physical parameters}

The solubility coefficients of NO in liquid phase $\left(H_{\mathrm{NO}, \mathrm{L}}\right)$ are calculated using the solubility coefficients of NO in water $\left(H_{\mathrm{NO}, \mathrm{w}}\right)$ and the Van Krevelen \& Hoftizer empirical equation. The diffusion coefficients of NO in liquid phase $\left(D_{\mathrm{NO}, \mathrm{L}}\right)$ are calculated using the diffusion coefficients of NO in water $\left(D_{\mathrm{NO}, \mathrm{w}}\right)$ and the Wilke-Chang empirical equation. The $H_{\mathrm{NO}, \mathrm{w}}$ and $D_{\mathrm{NO}, \mathrm{w}}$ can be obtained by consulting references. ${ }^{\mathbf{1 4 , 3 1}}$ The 
diffusion coefficients of NO in gas phase $\left(D_{\mathrm{NO}, \mathrm{G}}\right)$ are estimated by the Chapman-Enskog semi-empirical equation. ${ }^{32}$

\subsection{Mass transfer parameters}

It is difficult to directly measure the mass transfer coefficients of NO in gas-liquid reaction. For instead, the mass transfer parameters of the $\mathrm{CO}_{2}$ absorption system can be determined. Then they can be used to calculate the mass transfer coefficients of NO in gas-liquid reaction according to the following equations.

$$
\begin{gathered}
k_{\mathrm{NO}, \mathrm{L}}=k_{\mathrm{CO}_{2}, \mathrm{~L}} \times \frac{D_{\mathrm{NO}, \mathrm{L}}}{D_{\mathrm{CO}_{2}, \mathrm{~L}}} \\
k_{\mathrm{NO}, \mathrm{G}}=k_{\mathrm{CO}_{2}, \mathrm{G}} \times \frac{D_{\mathrm{NO}, \mathrm{G}}}{D_{\mathrm{CO}_{2}, \mathrm{G}}} \\
a_{\mathrm{NO}}=a_{\mathrm{CO}_{2}}
\end{gathered}
$$

where $k_{\mathrm{NO}, \mathrm{L}}$ and $k_{\mathrm{CO}_{2}, \mathrm{~L}}$ are the liquid phase mass transfer coefficients of $\mathrm{NO}$ and $\mathrm{CO}_{2}$, respectively, $\mathrm{m} \mathrm{s}^{-1} ; D_{\mathrm{NO}, \mathrm{L}}$ and $D_{\mathrm{CO}_{2}, \mathrm{~L}}$ are the liquid phase diffusion coefficients of $\mathrm{NO}$ and $\mathrm{CO}_{2}$, respectively, $\mathrm{m}^{2} \mathrm{~s}^{-1} ; k_{\mathrm{NO}, \mathrm{G}}$ and $k_{\mathrm{CO}_{2}, \mathrm{G}}$ are the gas phase mass transfer coefficients of $\mathrm{NO}$ and $\mathrm{CO}_{2}$, respectively, mol m${ }^{-2} \mathrm{~s}^{-1} \mathrm{~Pa}^{-1}$; $D_{\mathrm{NO}, \mathrm{G}}$ and $D_{\mathrm{CO}_{2}, \mathrm{G}}$ are the gas phase diffusion coefficients of NO and $\mathrm{CO}_{2}$, respectively, $\mathrm{m}^{2} \mathrm{~s}^{-1} ; a_{\mathrm{NO}}$ and $a_{\mathrm{CO}_{2}}$ are the gas-liquid specific interfacial areas of $\mathrm{NO}$ and $\mathrm{CO}_{2}$, respectively, $\mathrm{m}^{2} \mathrm{~m}^{-3}$.

The gas-liquid mass transfer parameters $\left(k_{\mathrm{CO}_{2}, \mathrm{~L}}\right.$ and $\left.a_{\mathrm{CO}_{2}}\right)$ of a $\mathrm{CO}_{2}$ absorption system are determined by the classical chemical methods, including the absorption of $\mathrm{CO}_{2}$ in NaClO$\mathrm{Na}_{2} \mathrm{CO}_{2} / \mathrm{NaHCO}_{3}$ solution and the absorption of $\mathrm{CO}_{2}$ in $\mathrm{NaOH}$ solution, and Danckwerts plot theory. Then $k_{\mathrm{NO}, \mathrm{L}}$ and $a_{\mathrm{NO}}$ are obtained as follows:

$$
\begin{gathered}
\ln k_{\mathrm{NO}, \mathrm{L}}=-0.23 \times \ln Q_{\mathrm{G}}-\frac{20.9}{273+T}-5.12 \\
\ln a_{\mathrm{NO}}=1.07 \times \ln Q_{\mathrm{G}}+\frac{3.49}{273+T}+3.27
\end{gathered}
$$

where $T$ is the gas temperature, ${ }^{\circ} \mathrm{C}$. Similarly, the gas-liquid mass transfer parameter $\left(k_{\mathrm{NO}, \mathrm{G}}\right)$ of $\mathrm{NO}$ absorption can be obtained by the following relation:

$$
\ln k_{\mathrm{NO}, \mathrm{G}}=0.35 \times \ln Q_{\mathrm{G}}-0.08 \times \ln \frac{1}{273+T}-14.73
$$

The physical and mass transfer parameters of our NO absorption system are summarized in Table 1 . The related parameters for NO absorption are under conditions of solution temperature $20^{\circ} \mathrm{C}$ and gas flow rate of $1.25 \mathrm{~L} \mathrm{~min}^{-1}$.

\section{Results and discussion}

\subsection{Effects of process parameters on NO absorption rate}

3.1.1 Effects of active chlorine concentration. The effects of active chlorine concentration in electrolyzed seawater solution on the absorption rate of NO were evaluated, and the results are shown in Fig. 2. When the active chlorine concentration was increased from 500 to $3100 \mathrm{mg} \mathrm{L}^{-1}\left[\mathrm{Cl}_{2}\right]$, the $\mathrm{NO}$ absorption rate significantly increased from $0.41 \times 10^{-5}$ to $1.91 \times 10^{-5} \mathrm{~mol}$ $\mathrm{m}^{-2} \mathrm{~s}^{-1}$. This can be explained by the theory of chemical reaction kinetics. The increase of reactant concentration will increase the reaction rate between active chlorine species and $\mathrm{NO}$, thereby increasing the NO absorption rate. But it seems that the increase of the NO absorption rate becomes a little slower with the increasing of active chlorine concentration. That is because the NO absorption reaction is a gas-liquid heterogeneous reaction, which is simultaneously controlled by chemical reaction and mass transfer. So it is possible that the increase of NO absorption rate will become insignificant when the active chlorine concentration is relatively high.

3.1.2 Effects of NO inlet concentration. The effects of NO inlet concentration on $\mathrm{NO}$ absorption rate were studied, and the results are shown in Fig. 3. It can be seen that, NO absorption rate greatly increased from $0.25 \times 10^{-5}$ to $1.58 \times 10^{-5} \mathrm{~mol} \mathrm{~m}^{-2}$ $\mathrm{s}^{-1}$ with NO concentration increasing from 250 to $1250 \mathrm{ppm}$. According to the two-film theory, an increase in NO concentration will increase the mass transfer driving force of NO in the gas-phase side, thereby increasing the reaction rate of active chlorine species with NO at the gas-liquid interface. That is the main reason for the increasing of NO absorption rate. In

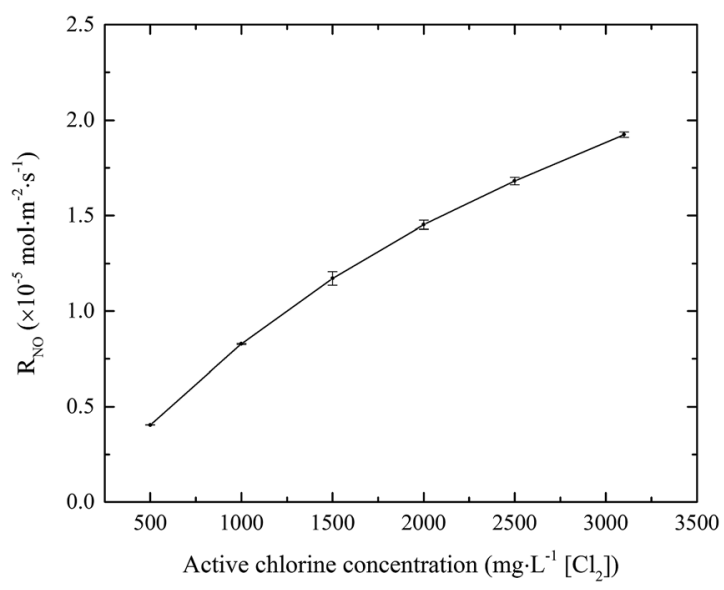

Fig. 2 Effects of active chlorine concentration on $\mathrm{NO}$ absorption rate (conditions: NO inlet concentration, 1000 ppm; $\mathrm{SO}_{2}$ inlet concentration, 0 ppm; solution $\mathrm{pH}, 7$; absorbent temperature, $20^{\circ} \mathrm{C}$ ).

Table 1 Physical and mass transfer parameters of the NO absorption system

\begin{tabular}{llll}
\hline$H_{\mathrm{NO}, \mathrm{L}} \times 10^{7}\left(\mathrm{~mol} \mathrm{~Pa}^{-1} \mathrm{~L}^{-1}\right)$ & $D_{\mathrm{NO}, \mathrm{L}} \times 10^{9}\left(\mathrm{~m}^{-2} \mathrm{~s}^{-1}\right)$ & $k_{\mathrm{NO}, \mathrm{L}} \times 10^{5}\left(\mathrm{~m} \mathrm{~s}^{-1}\right)$ & $k_{\mathrm{NO}, \mathrm{G}} \times 10^{7}\left(\mathrm{~mol} \mathrm{~m}^{-2} \mathrm{~s}^{-1} \mathrm{~Pa}^{-1}\right)$ \\
\hline 1.98 & 2.04 & 5.52 & $a_{\mathrm{NO}} \times 10\left(\mathrm{~m}^{2} \mathrm{~m}^{-3}\right)$ \\
\hline & 1.97 & 2.04
\end{tabular}




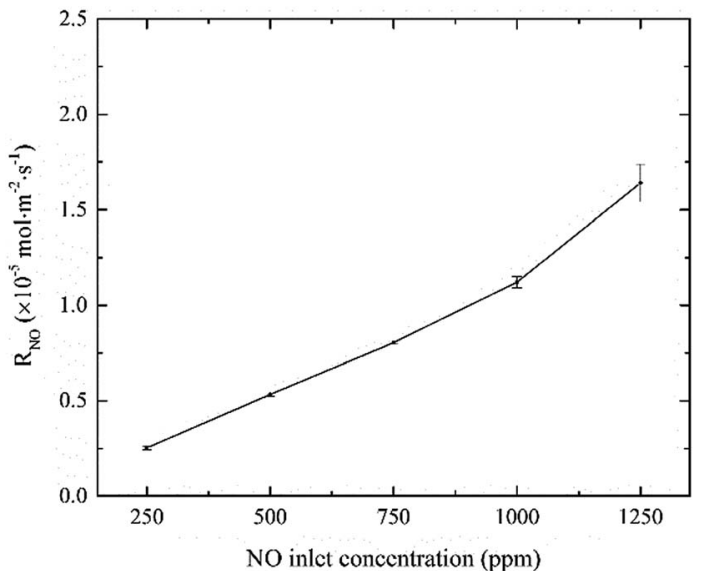

Fig. 3 Effects of $\mathrm{NO}$ inlet concentration on $\mathrm{NO}$ absorption rate (conditions: active chlorine concentration, $1500 \mathrm{mg} \mathrm{L}^{-1}\left[\mathrm{Cl}_{2}\right]$; $\mathrm{SO}_{2}$ inlet concentration, $0 \mathrm{ppm}$; solution $\mathrm{pH}, 7$; absorbent temperature, $20^{\circ} \mathrm{C}$ ).

addition, the curve showed almost linear relationship between the NO absorption rate and the NO inlet concentration as the other parameters remained constant. The results indicated that NO absorption by active chlorine in electrolyzed seawater was a first-order reaction with respect to NO concentration.

3.1.3 Effects of $\mathrm{SO}_{2}$ inlet concentration. The effects of $\mathrm{SO}_{2}$ concentration on $\mathrm{NO}$ absorption rate were investigated, and the results are shown in Fig. 4. When $\mathrm{SO}_{2}$ inlet concentration increased from 250 to $1250 \mathrm{ppm}, \mathrm{SO}_{2}$ was removed completely and NO absorption rate slightly increased from $1.07 \times 10^{-5}$ to $1.17 \times 10^{-5} \mathrm{~mol} \mathrm{~m}^{-2} \mathrm{~s}^{-1}$. Since $\mathrm{SO}_{2}$ is very soluble in water, it will be quickly absorbed and hydrolyzed into $\mathrm{HSO}_{3}{ }^{-}$and $\mathrm{SO}_{3}{ }^{2-}$ by eqn (8)-(10). These hydrolysis products will react with active chlorine in the electrolyzed seawater, competing with $\mathrm{NO}^{22}$ At the same time, the absorption of $\mathrm{SO}_{2}$ will lead to the decrease of solution $\mathrm{pH}$. It is known that the fractional compositions of active chlorine species in NaClO solution greatly changed with the solution $\mathrm{pH}$. With the decrease of solution $\mathrm{pH}$ from 7 to

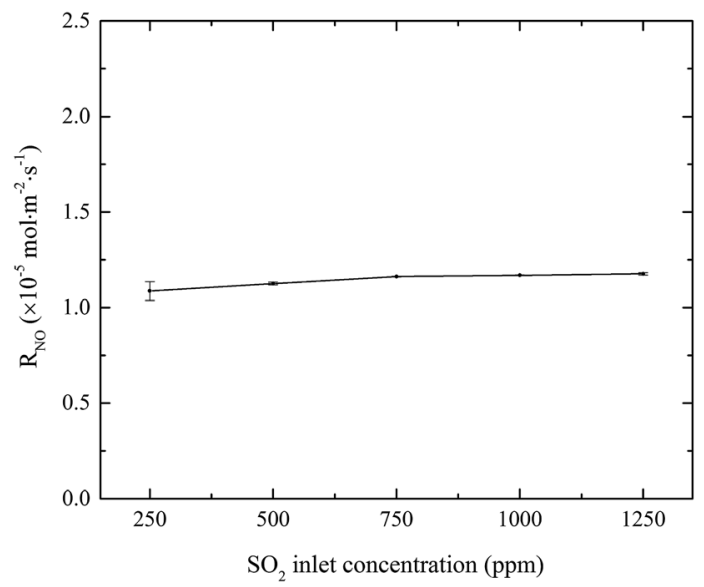

Fig. 4 Effects of $\mathrm{SO}_{2}$ concentration on $\mathrm{NO}$ absorption rate (conditions: active chlorine concentration, $1500 \mathrm{mg} \mathrm{L}^{-1}\left[\mathrm{Cl}_{2}\right]$; NO inlet concentration, $1000 \mathrm{ppm}$; solution $\mathrm{pH}$, 7; absorbent temperature, 20 $\left.{ }^{\circ} \mathrm{C}\right)$. a lower value (>5.3), the fractional concentration of $\mathrm{HClO}$ will increase ${ }^{20}$ Since $\mathrm{HClO}$ plays the key role in oxidizing NO into $\mathrm{NO}_{2}$, so the generation of $\mathrm{H}^{+}$might be favorable to increasing the NO absorption rate for electro-chlorine system. ${ }^{23}$

$$
\begin{aligned}
& \mathrm{SO}_{2(\mathrm{~g})} \rightarrow \mathrm{SO}_{2(\mathrm{l})} \\
& \mathrm{SO}_{2(1)}+\mathrm{H}_{2} \mathrm{O} \rightarrow \mathrm{H}_{2} \mathrm{SO}_{3} \\
& \mathrm{H}_{2} \mathrm{SO}_{3} \leftrightarrow \mathrm{HSO}_{3}{ }^{-}+\mathrm{H}^{+} \leftrightarrow \mathrm{SO}_{3}{ }^{2-}+2 \mathrm{H}^{+} \\
& \mathrm{HSO}_{3}{ }^{-}+\mathrm{HClO} / \mathrm{ClO}^{-} \rightarrow \mathrm{SO}_{4}^{-}+\mathrm{H}^{+}+\mathrm{Cl}^{-} / \mathrm{H}^{+}+\mathrm{Cl}^{-} \\
& \mathrm{SO}_{3}{ }^{2-}+\mathrm{HClO} / \mathrm{ClO}^{-} \rightarrow \mathrm{SO}_{4}^{-}+\mathrm{Cl}^{-} / \mathrm{H}^{+}+\mathrm{Cl}^{-}
\end{aligned}
$$

Some previous studies also showed that the presence of low to moderate concentrations of $\mathrm{SO}_{2}(990-2520 \mathrm{ppm})$ could enhance NO removal. ${ }^{14,19,33-39}$ These could be due to the fact that, in the presence of $\mathrm{SO}_{2}$, there are also important side reactions between the bisulfite ion $\left(\mathrm{HSO}_{3}{ }^{-}\right)$and $\mathrm{NO}_{2(1)}$, nitrite $\left(\mathrm{NO}_{2}{ }^{-}\right)$or nitrous acid $\left(\mathrm{HNO}_{2}\right)$ by eqn (13)-(15) to produce N-S intermediates such as hydroxylamine disulfonate $\left(\mathrm{HON}\left(\mathrm{SO}_{3}\right)_{2}{ }^{2-}\right)$ and nitrososulfonic acid $\left(\mathrm{ONSO}_{3}{ }^{-}\right.$or NSS), which have been identified by a number of investigators. ${ }^{14,33,40-48}$

$$
\begin{gathered}
2 \mathrm{NO}_{2(1)}+\mathrm{HSO}_{3}^{-}+\mathrm{H}_{2} \mathrm{O} \rightarrow 2 \mathrm{NO}_{2}^{-}+\mathrm{SO}_{4}{ }^{2-}+3 \mathrm{H}^{+} \\
\left.\mathrm{NO}_{2}{ }^{-}+\mathrm{H}^{+}+2 \mathrm{HSO}_{3}^{-} \leftrightarrow \mathrm{HON}^{-} \mathrm{SO}_{3}\right)_{2}{ }^{2-}+\mathrm{H}_{2} \mathrm{O} \\
\mathrm{NO}_{2}{ }^{-}+\mathrm{H}^{+}+\mathrm{HSO}_{3}^{-} \rightarrow \mathrm{ONSO}_{3}^{-}+\mathrm{H}_{2} \mathrm{O}
\end{gathered}
$$

Which of these reactions predominates will depend on the concentrations of the components, the temperature, and the $\mathrm{pH}$ of the solution. ${ }^{41}$ Furthermore, the stoichiometry and the rates for the reactions between $\mathrm{S}(\mathrm{Iv})$ ions $\left(\mathrm{HSO}_{3}{ }^{-}\right.$and $\mathrm{SO}_{3}{ }^{2-}$ ) and $\mathrm{NO}_{2}$ in aqueous solutions have been studied by many researchers..$^{40-42,49,50}$ The reaction of $\mathrm{NO}_{2(1)}$ with sulphite $\left(\mathrm{SO}_{3}{ }^{2-}\right)$ is considered to be significantly more rapid than with bisulfite $\left(\mathrm{HSO}_{3}{ }^{-}\right)$with an overall stoichiometry: ${ }^{49-51}$

$$
2 \mathrm{NO}_{2(1)}+\mathrm{SO}_{3}{ }^{-}+\mathrm{H}_{2} \mathrm{O} \rightarrow 2 \mathrm{NO}_{2}{ }^{-}+\mathrm{SO}_{4}{ }^{2-}+2 \mathrm{H}^{+}
$$

But Littlejohn et al. thought that the main loss mechanism for nitrite ion was the reaction with bisulfite to form $\mathrm{N}-\mathrm{S}$ compounds. ${ }^{40}$

3.1.4 Effects of solution $\mathbf{p H}$. The effects of solution initial $\mathrm{pH}$ value on NO absorption rate were evaluated, and the results are shown in Fig. 5. As the fractional compositions of active chlorine species in electro-chlorine system greatly depended on the solution $\mathrm{pH}$, the $\mathrm{NO}$ absorption rate changed obviously with the solution $\mathrm{pH}^{20}$ When solution $\mathrm{pH}$ increased from 3 to 4 , the fractional concentration of $\mathrm{HClO}$ increased largely, resulting in the increase of $\mathrm{NO}$ absorption rate. When solution $\mathrm{pH}$ was in the range of 4-6, the majority active chlorine species existed in the form of $\mathrm{HClO}$, which could oxidize $\mathrm{NO}$ into $\mathrm{NO}_{2}$ effectively. The result indicated that the reaction rate of $\mathrm{NO}$ with $\mathrm{HClO}$ was independent to the solution $\mathrm{pH}$ when the $\mathrm{pH}$ was in the range of 4-6. It was possible that the $\mathrm{HClO}$ concentration was relatively 


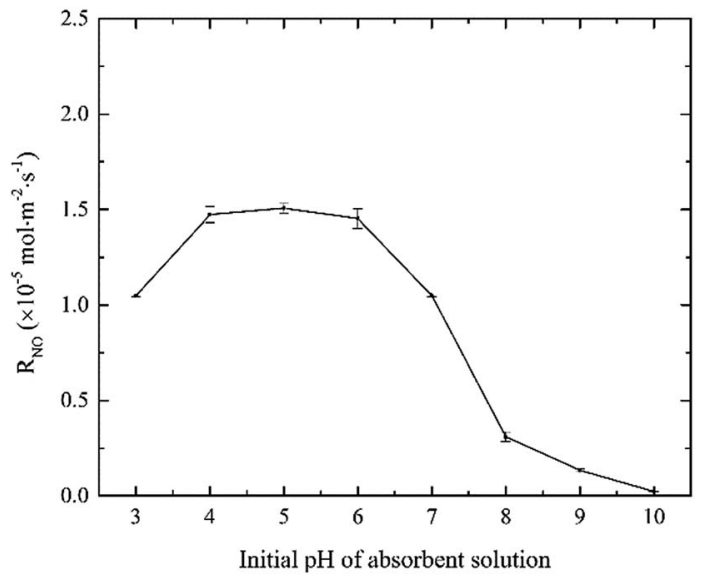

Fig. 5 Effects of solution $\mathrm{pH}$ value on $\mathrm{NO}$ absorption rate (conditions: active chlorine concentration, $1500 \mathrm{mg} \mathrm{L}^{-1}\left[\mathrm{Cl}_{2}\right]$; NO inlet concentration, $1000 \mathrm{ppm} ; \mathrm{SO}_{2}$ inlet concentration, 0 ppm; absorbent temperature, $20^{\circ} \mathrm{C}$ ).

excessive at that moment. However, when solution $\mathrm{pH}$ decreased from 6 to 10, NO absorption rate decreased largely from $1.45 \times 10^{-5}$ to $0.02 \times 10^{-5} \mathrm{~mol} \mathrm{~m}^{-2} \mathrm{~s}^{-1}$. It was mainly ascribed to the decrease of the fractional concentration of $\mathrm{HClO}$ in the electro-chlorine system. In alkaline medium, the active chlorine species mainly existed in the form of $\mathrm{ClO}^{-}$. Although the oxidability of $\mathrm{ClO}^{-}$was high, there was no evidence that $\mathrm{ClO}^{-}$could oxidize $\mathrm{NO}$ into $\mathrm{NO}_{2}$ effectively. ${ }^{23,24}$

3.1.5 Effects of absorbent temperature. The effects of absorbent temperature on NO absorption rate were studied, and the results are shown in Fig. 6. It can be seen that, the change of NO absorption rate was insignificant with the absorbent temperature increasing from 20 to $50{ }^{\circ} \mathrm{C}$. Generally, according to theories of gas-liquid mass transfer and chemical reaction kinetics, the increase of absorbent temperature will increase the mass transfer driving force of NO and active chlorine species in the gas-liquid two phases. Thus it is possible to

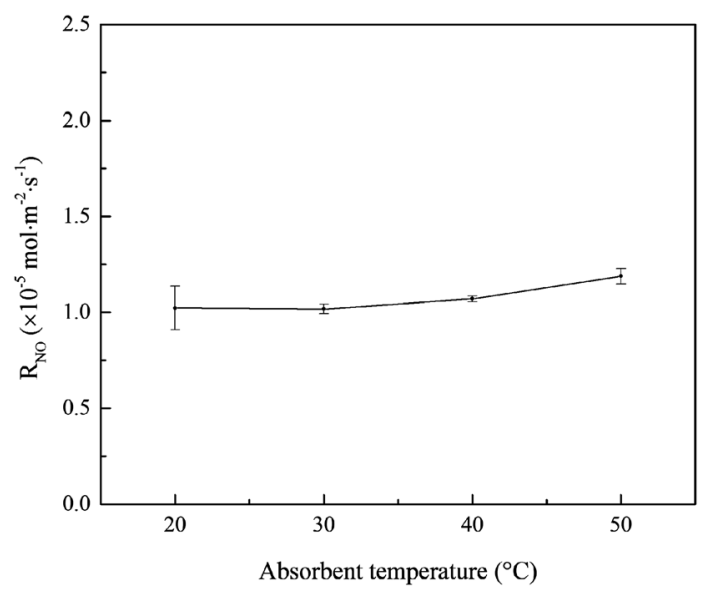

Fig. 6 Effects of absorbent temperature on $\mathrm{NO}$ absorption rate (conditions: active chlorine concentration, $1500 \mathrm{mg} \mathrm{L}^{-1}\left[\mathrm{Cl}_{2}\right]$; NO inlet concentration, 1000 ppm; $\mathrm{SO}_{2}$ inlet concentration, 0 ppm; solution $\mathrm{pH}, 7)$. obtain an increased NO absorption rate. But it was worthy to note that, the increase of absorbent temperature might decrease the solubility of $\mathrm{NO}_{x}$ in water solution. Thus the absorbent temperature imposed little effect on NO absorption rate in this experiment.

3.1.6 Analysis of reaction products. To verify the NO absorption by wet scrubbing using electrolyzed seawater, the anions of $\mathrm{NO}_{3}{ }^{-}$and $\mathrm{NO}_{2}{ }^{-}$in the scrubbing solution were measured via IC. The related experimental conditions were: active chlorine concentration, $1500 \mathrm{mg} \mathrm{L}^{-1}\left[\mathrm{Cl}_{2}\right]$; NO inlet concentration, $1000 \mathrm{ppm} ; \mathrm{SO}_{2}$ inlet concentration, $0 \mathrm{ppm}$; initial solution $\mathrm{pH}, 7$; absorbent temperature, $20{ }^{\circ} \mathrm{C}$. The bubbling process lasted for $30 \mathrm{~min}$, and the sample solutions was withdrawn from the bubbling reactor every $10 \mathrm{~min}$. $\mathrm{As} \mathrm{Cl}^{-}$ concentration in electrolyzed seawater was too high for IC measurement, the sample solutions was diluted 10 times, and then filtered by $\mathrm{Ag}$ cartridge and $\mathrm{H}$ cartridge, successively, in order to remove the majority of chloride ions. For each sample solution, IC tests were replicated for 3 times. The results showed that there was no $\mathrm{NO}_{2}^{-}$in the sample solutions. It indicated that most of the absorbed $\mathrm{NO}$ was turned into $\mathrm{NO}_{3}{ }^{-}$. The measured values and calculated values of $\mathrm{NO}_{3}{ }^{-}$were listed in Table 2. It was thought that, the errors between the measured values and calculated ones mainly resulted from the sampling and processing procedure. With the increase of bubbling duration, the $\mathrm{NO}_{3}{ }^{-}$concentration increased accordingly. Thus the results reflected the NO absorption during the wet scrubbing using electrolyzed seawater properly.

\subsection{Kinetics of NO absorption}

3.2.1 Theoretical fundamentals. As mentioned above, the effective components for NO absorption in electro-chlorine system was $\mathrm{HClO}$, according to the previous studies of NO removal by wet scrubbing using sodium hypochlorite $(\mathrm{NaClO})$ solution. ${ }^{21,24,30,52}$ The reaction rate of $\mathrm{NO}$ with $\mathrm{ClO}^{-}$was much slower than that of $\mathrm{NO}$ with $\mathrm{HClO},{ }^{23}$ so the oxidation and absorption of NO in electro-chlorine system mainly referred to the reactions between NO and HClO.

$$
2 \mathrm{NO}+3 \mathrm{HOCl}+\mathrm{H}_{2} \mathrm{O} \rightarrow 2 \mathrm{HNO}_{3}+3 \mathrm{HCl}
$$

According to the chemical reaction kinetic theory, ${ }^{31,53}$ the NO removal by electro-generated chlorine can be regarded as a partial $j$-order reaction for $\mathrm{H}_{2} \mathrm{O}$, a partial $m$-order reaction for $\mathrm{NO}$ and a partial $n$-order reaction for $\mathrm{HOCl}$, respectively. The

Table 2 The measured values and calculated values of $\mathrm{NO}_{3}{ }^{-}$ concentrations in the sample solutions

\begin{tabular}{llll}
\hline Duration $(\mathrm{min})$ & $\begin{array}{l}\text { Measured values } \\
\left(\mathrm{mg} \mathrm{L}^{-1}\right)\end{array}$ & $\begin{array}{l}\text { Calculated values } \\
\left(\mathrm{mg} \mathrm{L}^{-1}\right)\end{array}$ & Errors (\%) \\
\hline 10 & & & \\
20 & 18.04 & 22.30 & 19.10 \\
30 & 35.43 & 45.72 & 22.51 \\
& 66.75 & 70.26 & 5.00
\end{tabular}


chemical reaction rate equation can be expressed as the following equation:

$$
R_{\mathrm{NO}}=k_{j, m, n} \times C_{\mathrm{H}_{2} \mathrm{O}}{ }^{i} \times C_{\mathrm{NO}, i}{ }^{m} \times C_{\mathrm{HOCl}}{ }^{n}
$$

where $k_{j, m, n}$ is $(j+m+n)$ order rate constant for the overall reaction (17); $C_{\mathrm{H}_{2} \mathrm{O}}$ is $\mathrm{H}_{2} \mathrm{O}$ concentration in liquid phase, mol $\mathrm{L}^{-1} ; C_{\mathrm{NO}, \mathrm{i}}$ is the NO concentration at gas-liquid interface, mol $\mathrm{L}^{-1} ; C_{\mathrm{HOCl}}$ is the electro-generated chlorine concentration in bulk liquid phase, $\mathrm{mol} \mathrm{L}^{-1} ; j$ is partial reaction order for $\mathrm{H}_{2} \mathrm{O} ; m$ is partial reaction order for NO; $n$ is partial reaction order for HOCl.

As $\mathrm{H}_{2} \mathrm{O}$ is the solvent of the bubbling liquid, $C_{\mathrm{H}_{2} \mathrm{O}}$ is considered to be infinite, so it could be regarded as a constant compared to $C_{\mathrm{NO}, \mathrm{i}}$ and $C_{\mathrm{HOCl}}$. Thus the chemical reaction of NO absorption can be regarded as a pseudo- $m$-order reaction for NO and a pseudo- $n$-order reaction for $\mathrm{HOCl}$. The NO absorption rate equation can be further simplified to the following equation:

$$
R_{\mathrm{NO}}=k_{m, n} \times C_{\mathrm{NO}, \mathrm{i}}{ }^{m} \times C_{\mathrm{HOCl}}{ }^{n}
$$

where $k_{m, n}=k_{j, m, n} \times C_{\mathrm{H}_{2} \mathrm{O}}$ is pseudo- $(m+n)$-order rate constant for $\mathrm{NO}$ and $\mathrm{HOCl}$.

According to two-film theory, the NO absorption rate can be described as: ${ }^{54}$

$$
\begin{aligned}
R_{\mathrm{NO}} & =k_{\mathrm{NO}, \mathrm{G}} \times\left(p_{\mathrm{NO}, \mathrm{G}}-p_{\mathrm{NO}, \mathrm{i}}\right) \\
& =E \times k_{\mathrm{NO}, \mathrm{L}} \times\left(C_{\mathrm{NO}, \mathrm{i}}-C_{\mathrm{NO}, \mathrm{L}}\right)
\end{aligned}
$$

where $R_{\mathrm{NO}}$ is the NO absorption rate, $\mathrm{mol} \mathrm{m} \mathrm{m}^{-2} \mathrm{~s}^{-1} ; p_{\mathrm{NO}, \mathrm{G}}$ is the partial pressure of $\mathrm{NO}$ in the bulk gas, $\mathrm{Pa} ; p_{\mathrm{NO}, \mathrm{i}}$ is the partial pressure of $\mathrm{NO}$ at gas-liquid interface, $\mathrm{Pa} ; C_{\mathrm{NO}, \mathrm{L}}$ is the $\mathrm{NO}$ concentration in the bulk liquid phase, $\mathrm{mol} \mathrm{L}^{-1} ; E$ is the chemical reaction enhancement factor.

According to the Henry law, the equilibrium relationship at the gas-liquid interface can be obtained as:

$$
C_{\mathrm{NO}, \mathrm{i}}=H_{\mathrm{NO}, \mathrm{L}} \times p_{\mathrm{NO}, \mathrm{i}}
$$

where $H_{\mathrm{NO}, \mathrm{L}}$ is solubility coefficient of $\mathrm{NO}$ in solution, $\mathrm{mol} \mathrm{L}^{-1}$ $\mathrm{Pa}^{-1}$. Then the NO absorption rate equation can be rearranged to the following eqn (22) through solving the above eqn (20) and (21).

$$
R_{\mathrm{NO}}=\frac{p_{\mathrm{NO}, \mathrm{G}}-\frac{C_{\mathrm{NO}, \mathrm{L}}}{H_{\mathrm{NO}, \mathrm{L}}}}{\frac{1}{k_{\mathrm{NO}, \mathrm{G}}}+\frac{1}{E \times H_{\mathrm{NO}, \mathrm{L}} \times k_{\mathrm{NO}, \mathrm{L}}}}
$$

According to the results of Guo R. T. et al. ${ }^{27}$ the NO absorption process was a first-order fast reaction with respect to both NO and NaClO concentrations when the experiments on NO absorption kinetics were performed with weakly acidic $\mathrm{NaClO}$ solution. In the present study, it was firstly supposed that the NO removal by electro-generated chlorine was a fast reaction. This hypothesis would be validated in the following section. For a fast reaction, NO was completely removed before it entered into the bulk liquid phase, according to the two-film theory, so that $C_{\mathrm{NO}, \mathrm{L}}=0$. Therefore, the NO absorption rate eqn (22) can be further simplified to the following equation:

$$
R_{\mathrm{NO}}=\frac{p_{\mathrm{NO}, \mathrm{G}}}{\frac{1}{k_{\mathrm{NO}, \mathrm{G}}}+\frac{1}{E \times H_{\mathrm{NO}, \mathrm{L}} \times k_{\mathrm{NO}, \mathrm{L}}}}
$$

Furthermore, for an irreversible pseudo-m-order reaction, the chemical reaction enhancement factor $E$ can be approximated as:

$$
E=\frac{H_{\mathrm{a}} \times\left[\left(E_{\mathrm{i}}-E\right) /\left(E_{\mathrm{i}}-1\right)\right]^{n / 2}}{\tanh \left\{H_{\mathrm{a}} \times\left[\left(E_{\mathrm{i}}-E\right) /\left(E_{\mathrm{i}}-1\right)\right]^{n / 2}\right\}}
$$

where $E_{\mathrm{i}}$ is the enhancement factor for the instantaneous reaction; $H_{\mathrm{a}}$ is defined as the ratio of the maximum possible conversion in the film to the maximum diffusion transport through the film, which is given by:

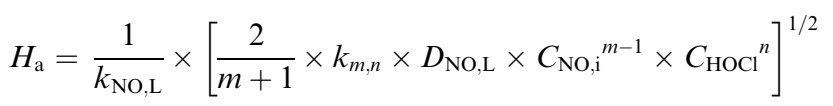

When the NO absorption process is a fast reaction, $H_{\mathrm{a}}>3.0$, and there is $E=H_{\mathrm{a}}$. Thus, the NO absorption rate eqn (23) can be further expressed as follows:

$$
=\frac{R_{\mathrm{NO}}}{\frac{1}{k_{\mathrm{NO}, \mathrm{G}}}+\frac{p_{\mathrm{NO}, \mathrm{G}}}{H_{\mathrm{NO}, \mathrm{L}} \times \sqrt{\frac{2}{m+1} \times D_{\mathrm{NO}, \mathrm{L}} \times k_{m, n} \times C_{\mathrm{NO}, \mathrm{i}}{ }^{m-1} \times C_{\mathrm{HOCl}}{ }^{n}}}}
$$

When active chlorine concentration of $1500 \mathrm{mg} \mathrm{L}^{-1}\left[\mathrm{Cl}_{2}\right]$ and NO inlet concentration of 1000 ppm were taken into consideration, the molar concentration of active chlorine in electrochlorine system $\left(2.1 \times 10^{-2} \mathrm{~mol} \mathrm{~L}^{-1}\right)$ was about 495 times higher than that of NO $\left(4.24 \times 10^{-5} \mathrm{~mol} \mathrm{~L}^{-1}\right)$. Thus the active chlorine concentration in electro-chlorine system could be regarded as a constant parameter during each experiment run. So the eqn (25) and (26) could be further simplified as follows:

$$
\begin{aligned}
H_{\mathrm{a}} & =\frac{1}{k_{\mathrm{NO}, \mathrm{L}}} \times\left[\frac{2}{m+1} \times k_{m, n} \times D_{\mathrm{NO}, \mathrm{L}} \times C_{\mathrm{NO}, \mathrm{i}}{ }^{m-1}\right]^{1 / 2} \\
R_{\mathrm{NO}} & =\frac{1}{k_{\mathrm{NO}, \mathrm{G}}}+\frac{1}{H_{\mathrm{NO}, \mathrm{L}} \times \sqrt{\frac{2}{m+1} \times D_{\mathrm{NO}, \mathrm{L}} \times k_{m, n} \times C_{\mathrm{NO}, \mathrm{i}}{ }^{m-1}}}
\end{aligned}
$$

3.2.2 Determination of reaction order for NO. The kinetics of NO concentration could be obtained from the transformation of eqn (28): 


$$
\begin{aligned}
& \frac{R_{\mathrm{NO}} \times k_{\mathrm{NO}, \mathrm{G}}}{H_{\mathrm{NO}, \mathrm{L}} \times\left(p_{\mathrm{NO}, \mathrm{G}} \times k_{\mathrm{NO}, \mathrm{G}}-R_{\mathrm{NO}}\right)} \\
& =\left(\frac{2 \times D_{\mathrm{NO}, \mathrm{L}} \times k_{m, n} \times C_{\mathrm{NO}, \mathrm{i}}{ }^{m-1}}{m+1}\right)^{1 / 2}
\end{aligned}
$$

NO interface concentration could be expressed as eqn (30) by combining the eqn (20) and (21):

$$
C_{\mathrm{NO}, \mathrm{i}}=H_{\mathrm{NO}, \mathrm{L}} \times\left(p_{\mathrm{NO}, \mathrm{G}}-\frac{R_{\mathrm{NO}}}{k_{\mathrm{NO}, \mathrm{G}}}\right)
$$

Through solving the above eqn (29) and (30), NO absorption rate could be expressed as the following equation:

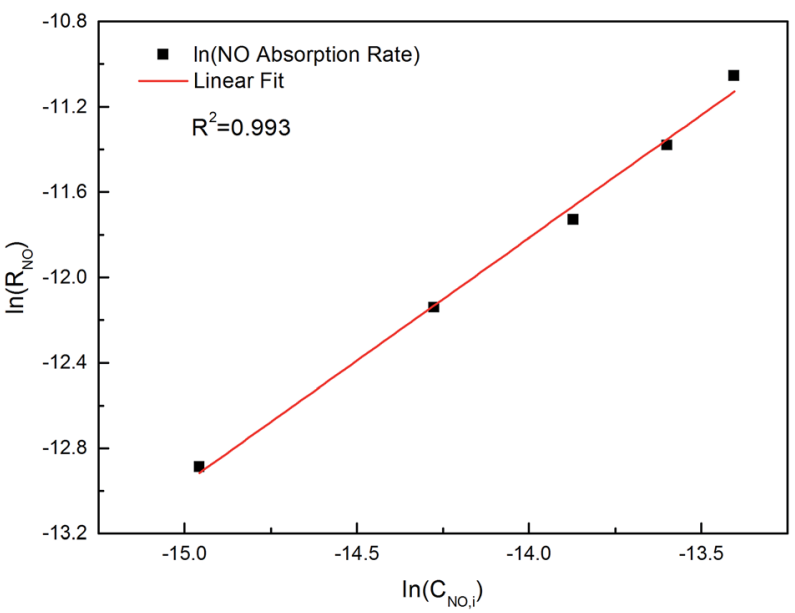

Fig. 7 Plot of $\log \left(R_{\mathrm{NO}}\right)$ versus $\log \left(C_{\mathrm{NO}, i}\right)$ (conditions: active chlorine concentration, $1500 \mathrm{mg} \mathrm{L}^{-1}\left[\mathrm{Cl}_{2}\right]$; NO inlet concentration, $1000 \mathrm{ppm}$; solution $\mathrm{pH}$, 7; gas flow, $1.25 \mathrm{~L} \mathrm{~min}^{-1}$; absorbent temperature, $20{ }^{\circ} \mathrm{C}$ ).

$$
R_{\mathrm{NO}}=\left(\frac{2 \times D_{\mathrm{NO}, \mathrm{L}} \times k_{m, n} \times C_{\mathrm{NO}, \mathrm{i}}{ }^{m+1}}{m+1}\right)^{1 / 2}
$$

The following eqn (32) could be obtained by taking a logarithm on both sides of the eqn (31):

$$
\ln R_{\mathrm{NO}}=\frac{1}{2} \times \ln \frac{2 \times k_{m, n} \times D_{\mathrm{NO}, \mathrm{L}}}{m+1}+\frac{m+1}{2} \times \ln c_{\mathrm{NO}, \mathrm{i}}
$$

The relationship between $\ln \left(R_{\mathrm{NO}}\right)$ and $\ln \left(C_{\mathrm{NO}, \mathrm{i}}\right)$ is presented in Fig. 7. The slope of the fitted line was 1.15 . That was $(m+1) / 2$ $=1.15$. Therefore, the reaction order of NO concentration $m$ was 1.3 , taking the integer $m=1$. It indicated that the NO absorption by wet scrubbing electrolyzed seawater was a pseudo-firstorder reaction with respect to the NO concentration. Thus the equation of NO absorption rate could be expressed as follows:

$$
N_{\mathrm{NO}}=p_{\mathrm{NO}, \mathrm{G}} \times\left(\frac{1}{k_{\mathrm{NO}, \mathrm{G}}}+\frac{1}{H_{\mathrm{NO}, \mathrm{L}} \times \sqrt{D_{\mathrm{NO}, \mathrm{L}} \times k_{m, n}}}\right)^{-1}
$$

\subsubsection{Reaction rate constant and validation of NO absorp-} tion rate equations. The $(m+n)$ order rate constant $\left(k_{m, n}\right)$ for the reaction (17) could be calculated by eqn (1) and (33), and the results are summarized in Table 3 . The related experimental conditions were $\mathrm{SO}_{2}$ inlet concentration of $0 \mathrm{ppm}$; solution $\mathrm{pH}$ of 7 ; and absorbent temperature of $20{ }^{\circ} \mathrm{C}$.

$$
k_{m, n}=\left(D_{\mathrm{NO}, \mathrm{L}}\right)^{-1} \times\left(\frac{p_{\mathrm{NO}, \mathrm{G}} \times H_{\mathrm{NO}, \mathrm{L}}}{N_{\mathrm{NO}}}-\frac{H_{\mathrm{NO}, \mathrm{L}}}{k_{\mathrm{NO}, \mathrm{G}}}\right)^{-2}
$$

\begin{tabular}{|c|c|c|c|c|c|c|}
\hline Parameters & & $R_{\mathrm{NO}}{ }^{a}\left(10^{-5} \mathrm{~mol} \mathrm{~m}^{-2} \mathrm{~s}^{-1}\right)$ & $R_{\mathrm{NO}}{ }^{b}\left(10^{-5} \mathrm{~mol} \mathrm{~m}^{-2} \mathrm{~s}^{-1}\right)$ & Error $(\%)$ & $k_{m, n}\left(10^{-3} \mathrm{~s}^{-1}\right)$ & $H_{\mathrm{a}}$ \\
\hline \multirow{4}{*}{$C_{\mathrm{NO}} \operatorname{ppm}\left(1500 \mathrm{mg} \mathrm{L}^{-1}\left[\mathrm{Cl}_{2}\right]\right)$} & 250 & 0.25 & 0.27 & $7.4 \%$ & 0.32 & 3.9 \\
\hline & 500 & 0.53 & 0.52 & $-1.9 \%$ & 0.36 & 4.2 \\
\hline & 1000 & 0.11 & 1.14 & $2.6 \%$ & 0.43 & 4.6 \\
\hline & 1250 & 1.58 & 1.54 & $-2.6 \%$ & 0.56 & 5.2 \\
\hline \multirow[t]{3}{*}{$C_{\mathrm{NO}} \operatorname{ppm}\left(2500 \mathrm{mg} \mathrm{L}^{-1}\left[\mathrm{Cl}_{2}\right]\right)$} & 250 & 0.42 & 0.41 & $-2.4 \%$ & 1.20 & 7.6 \\
\hline & 1000 & 1.68 & 1.66 & $-1.2 \%$ & 1.21 & 7.6 \\
\hline & 1250 & 2.07 & 2.12 & $2.4 \%$ & 1.15 & 7.5 \\
\hline \multirow{4}{*}{$C_{\mathrm{ACC}} \mathrm{mg} \mathrm{L}^{-1}\left[\mathrm{Cl}_{2}\right](\mathrm{NO}, 1000 \mathrm{ppm})$} & 500 & 0.40 & 0.42 & $4.8 \%$ & 0.04 & 1.4 \\
\hline & 1000 & 0.83 & 0.82 & $-1.2 \%$ & 0.20 & 3.1 \\
\hline & 1500 & 1.17 & 1.14 & $-2.6 \%$ & 0.46 & 4.7 \\
\hline & 2000 & 1.45 & 1.42 & $-2.1 \%$ & 0.80 & 6.2 \\
\hline
\end{tabular}

According to the two-film theory, for a pseudo-first-order reaction with respect to NO concentration, the expression (21) of $H_{\mathrm{a}}$ could be further simplified to the following equation:

Table 3 Kinetic parameters of NO absorption by wet scrubbing using electrolyzed seawater

${ }^{a}$ Experimental values. ${ }^{b}$ Calculation values. 


$$
H_{\mathrm{a}}=\frac{\sqrt{D_{\mathrm{NO}, \mathrm{L}} \times k_{m, n}}}{k_{\mathrm{NO}, \mathrm{L}}}
$$

where $D_{\mathrm{NO}, \mathrm{L}}$ and $k_{\mathrm{NO}, \mathrm{L}}$ can be obtained in Table 1 . From Table 3, it can be seen that, all of the $H_{\mathrm{a}}$ are greater than 3.0. It indicates that the NO absorption by wet scrubbing using electrolyzed seawater is a fast chemical reaction under the present conditions.

In order to facilitate the calculation of $\mathrm{NO}$ absorption rate in the future industrial applications, the $(m+n)$ order rate constant $\left(k_{m, n}\right)$ for the reaction (17) are fitted into the following empirical eqn (36) with NO concentration, and active chlorine concentration.

$$
\begin{aligned}
k_{m, n}= & -4.32 \times 10^{3}-2.56 \times 10 \times C_{\mathrm{NO}}+5.16 \times C_{\mathrm{ACC}}+2.75 \\
& \times 10^{-2} \times C_{\mathrm{NO}}^{2}+1.68 \times 10^{-2} \times C_{\mathrm{ACC}}{ }^{2}
\end{aligned}
$$

$$
R^{2}=0.978
$$

The calculated values and the experimental values of NO absorption rates under different experimental conditions were compared, and the results are also shown in Table 3. It can be seen that under all the experimental conditions, the calculated values are in good agreement with the experimental values. The average error is $2.49 \%$ and the maximal error is less than $7.4 \%$ between the calculated values and the experimental values. It is acceptable in the study of the gas-liquid reaction. Thus NO absorption rate equation can be used to simulate the absorption process of NO absorption by wet scrubbing using electrolyzed seawater process, and offers some meaningful guidance for the design and amplification of the reactor to some extent.

\section{Conclusions}

The mass transfer-reaction kinetics of NO absorption by electrolyzed seawater was studied in a bubbling reactor. The effects of active chlorine concentration, solution $\mathrm{pH}$, absorbent temperature, $\mathrm{NO}$ and $\mathrm{SO}_{2}$ inlet concentrations on $\mathrm{NO}$ absorption rate were investigated. The results showed that, NO absorption rate significantly increased with the increase of active chlorine concentration and NO inlet concentration. NO absorption rate slightly increased with the increase of $\mathrm{SO}_{2}$ inlet concentration. Since the fractional compositions of active chlorine species in electrolyzed seawater greatly depended on the solution $\mathrm{pH}, \mathrm{NO}$ absorption rate obviously changed with the solution $\mathrm{pH}$. When solution $\mathrm{pH}$ was at $7, \mathrm{NO}$ absorption rate was $1.06 \times 10^{-5} \mathrm{~mol} \mathrm{~m}^{-2} \mathrm{~s}^{-1}$. The NO absorption process by electrolyzed seawater was pseudo-first-order reaction with respect to NO concentration. It was a fast chemical reaction in the present study. A simplified equation of $\mathrm{NO}$ absorption rate was established, and the comparison results indicated that the calculated values agreed well with the experimental values.

\section{Acknowledgements}

This paper was supported by the National Natural Science Foundation of China (No. 51402033 and 51479020), the Science and Technology Plan Project of China's Ministry of Transport (2015328225150) and the Fundamental Research Funds for the Central Universities (3132016018), and the Scientific Research Fund of Liaoning Provincial Education Department of China (No. L2014198). Dr Kaiying Liu was appreciated for the help of IC measurement.

\section{Notes and references}

1 Z. T. Han, S. L. Yang, D. K. Zheng, X. X. Pan and Z. J. Yan, SpringerPlus, 2016, 5, 751.

2 G. Busca, L. Lietti, G. Ramis and F. Berti, Appl. Catal., B, 1998, 18, 1-36.

3 M. T. Javed, N. Irfan and B. M. Gibbs, J. Environ. Manage., 2007, 83, 251-289.

4 S. L. Ding, Q. Yu, Y. Z. Zhang, Y. Liu, C. X. Xie and G. Yu, J. Adv. Oxid. Technol., 2015, 18, 114-122.

5 D. Y. Xie, Y. Sun, T. Zhu and L. Ding, Energy Fuels, 2016, 30, 5071-5076.

6 S. P. Guo, L. N. Lv, J. Zhang, X. Chen, M. Tong, W. Z. Kang, Y. B. Zhou and J. Lu, Chem. Ind. Chem. Eng. Q., 2015, 21, 305-310.

7 P. Fang, C. P. Cen, X. M. Wang, Z. J. Tang, Z. X. Tang and D. S. Chen, Fuel Process. Technol., 2013, 106, 645-653.

8 Y. Zhao, R. L. Hao, P. Zhang and S. H. Zhou, Energy Fuels, 2014, 28, 6502-6510.

9 Y. X. Liu, J. Zhang, C. D. Sheng, Y. C. Zhang and L. Zhao, Energy Fuels, 2010, 24, 4925-4930.

10 Y. X. Liu, J. F. Pan, A. K. Tang and Q. Wang, Fuel, 2013, 108, 254-260.

11 Y. X. Liu, J. Zhang and C. D. Sheng, Energy Fuels, 2011, 25, 1547-1552.

12 Z. P. Wang and Z. W. Wang, Ind. Eng. Chem. Res., 2015, 54, 9905-9912.

13 N. E. Khan and Y. G. Adewuyi, Ind. Eng. Chem. Res., 2010, 49, 8749-8760.

14 Y. G. Adewuyi and S. O. Owusu, Ind. Eng. Chem. Res., 2003, 42, 4084-4100.

15 Y. G. Adewuyi and S. O. Owusu, J. Phys. Chem. A, 2006, 110, 11098-11107.

16 N. D. Hutson and R. Krzyzynska, Ind. Eng. Chem. Res., 2008, 47, 5825-5831.

17 H. K. Lee, B. R. Deshwal and K. S. Yoo, Korean J. Chem. Eng., 2005, 22, 208-213.

18 Y. G. Adewuyi, X. He, H. Shaw and W. Lolertpihop, Chem. Eng. Commun., 1999, 174, 21-51.

19 B. R. Deshwal, D. S. Jin, S. H. Lee, S. H. Moon, J. H. Jung and H. K. Lee, J. Hazard. Mater., 2008, 150, 649-655.

20 Y. Zhou, C. T. Li, C. Z. Fan, M. F. Fu, L. Tao, M. G. Yu and M. Y. Zhang, Environ. Prog. Sustainable Energy, 2015, 34, 1586-1595.

21 M. K. Mondal and V. R. Chelluboyana, Chem. Eng. J., 2013, 217, 48-53.

22 Z. T. Han, S. L. Yang, X. X. Pan, D. S. Zhao, J. Q. Yu, Y. T. Zhou, P. F. Xia, D. K. Zheng, Y. H. Song and Z. J. Yan, Energy Fuels, 2017, 31, 3047-3054. 
23 E. Ghibaudi, J. R. Barker and S. W. Benson, Int. J. Chem. Kinet., 1979, 11, 843-851.

24 L. Chen, C. H. Hsu and C. L. Yang, Environ. Prog., 2005, 24, 279-288.

25 C. V. Raghunath and M. K. Mondal, Chem. Eng. J., 2016, 314, 537-547.

26 S. L. Yang, Z. T. Han, J. M. Dong, Z. S. Zheng and X. X. Pan, J. Chem., 2016, 2016, 6065019.

27 R. T. Guo, W. G. Pan, X. B. Zhang, H. J. Xu, Q. Jin, C. G. Ding and S. Y. Guo, Sep. Sci. Technol., 2013, 48, 2871-2875.

28 B. B. Deshwal and N. Kundu, Int. J. Adv. Res. Sci. Technol., 2015, 4, 313-318.

29 A. N. Sukheon and O. Nishida, JSME Int. J., Ser. B, 2003, 46, 206-213.

30 S. L. Yang, Z. T. Han, X. X. Pan, Z. J. Yan and J. Q. Yu, RSC $A d v .$, 2016, 6, 114623-114631.

31 C. F. Zhang, Gas-liquid Reaction and Reactors [M], Chemical Industry Press, Beijing, 1985.

32 Q. F. Ye, Gaseous mercury absorption from simulated flue gas [D], Zhejiang University, 2006.

33 Y. G. Adewuyi and N. Sakyi, Ind. Eng. Chem. Res., 2013, 52, 11702-11711.

34 T. W. Chien, H. T. Hsueh, B. Y. Chu and H. Chu, Process Saf. Environ. Prot., 2009, 87, 300-306.

35 E. B. Myers Jr and T. J. Overcamp, Environ. Eng. Sci., 2002, 321-327.

36 Y. Byun, K. B. Ko, M. Cho, W. Namkung, K. Lee, D. N. Shin and D. J. Koh, Environ. Sci. Technol., 2009, 43, 5054-5059.

37 Y. G. Adewuyi and N. E. Khan, AIChE J., 2012, 58, 2397-2411.

38 Y. G. Adewuyi and S. Owusu, J. Phys. Chem. A, 2006, 110, 11098-11107.

39 S. Owusu and Y. G. Adewuyi, Ind. Eng. Chem. Res., 2006, 45, 4475-4485.
40 D. Littlejohn and S. G. Chang, Energy Fuels, 1991, 5, 249-254.

41 M. A. Siddiqi, J. Petersen and K. Lucas, Ind. Eng. Chem. Res., 2001, 40, 2116-2127.

42 S. M. Petrissans and A. Zoulalian, Ind. Eng. Chem. Res., 2001, 40, 6068-6072.

43 M. A. Siddiqi, J. Petersen and K. Lucas, Ind. Eng. Chem. Res., 2003, 42, 1406-1413.

44 S. B. Oblath, S. S. Markowitz, T. Novakov and S. G. Chang, J. Phys. Chem., 1981, 85, 1017-1021.

45 S. B. Oblath, S. S. Markowitz, T. Novakov and S. G. Chang, J. Phys. Chem., 1982, 86, 4853-4857.

46 D. Littlejohn, K. Y. Hu and S. G. Chang, Inorg. Chem., 1986, 25, 3131-3135.

47 D. Littlejohn, Y. Wang and S. G. Chang, Environ. Sci. Technol., 1993, 27, 2162-2167.

48 S. G. Chang, D. Littlejohn and N. H. Lin, Kinetics of Reactions in a Wet Flue Gas Simultaneous Desulfurization and Denitrification System, American Chemical Society (ACS), Washington, DC, 1982, vol. 188, pp. 127-152.

49 C. H. Shen and G. T. Rochelle, Environ. Sci. Technol., 1998, 32, 1994-2003.

50 C. L. Clifton, N. Altstein and R. E. Huie, Environ. Sci. Technol., 1988, 22, 586-589.

51 C. H. Nelli and G. T. Rochelle, J. Air Waste Manage. Assoc., 1998, 48, 819-828.

52 Y. Li, W. Q. Zhong, J. Ju, T. C. Wang and F. Liu, Int. J. Chem. React. Eng., 2014, 12, 539-547.

$53 \mathrm{Y}$. Xu, Chemical reaction kinetics $[M]$, Chemical Industry Press, Beijing, 2004.

54 P. V. Danckwerts, Gas-Liquid Reactions [M], McGraw-Hill Book Company, 1970. 